грудня 2019 року № 361-IX. URL: https://zakon.rada.gov.ua/ laws/show/361-20?find=1\&text\#Text (дата звернення 19.10.2020).

3. Про затвердження Положення про здійснення банками фінансового моніторингу Постанова Національного банку України 19.05.2020 № 65. URL: https://zakon.rada.gov.ua/laws/show/v006550020\#Tехt (дата звернення 19.10.2020).

4. Про затвердження Положення про здійснення установами фінансового моніторингу Постанова Національного банку України 28.07.2020 № 107 URL: https://zakon.rada.gov.ua/laws/show/v010750020\#Tехt (дата звернення 19.10.2020).

5. Бортник, С. М. Соціальна інженерія як метод вчинення злочинів / Сергій Миколайович Бортник // Протидія кіберзагрозам та торгівлі людьми: зб. матеріалів Міжнар. наук.-практ. конф. (м. Харків, 26 листоп. 2019 р.) / МВС України, Харків. нац. ун-т внутр. справ ; Координатор проектів ОБСЄ в Україні. - Харків : ХНУВС, 2019. C. 34-35. URL: http://dspace.univd.edu.ua/xmlui/bitstream/handle/ 123456789/6425/Sotsialna\%20inzheneriia\%20yak\%20metod\%20vchynenni a\%20zlochyniv_Bortnyk\%20S_2019.pdf?sequence=1\&isAllowed=y (дата звернення 19.10.2020).

6. Протидія злочинам, що вчиняються за допомогою методів соціальної інженерії в інтернеті / Ю. М. Онищенко, К. Е. Петров, I. В. Кобзев // Право і Безпека. - 2017. - № 1. - С. 63-68. URL: http://nbuv.gov.ua/UJRN/Pib_2017_1_13 (дата звернення 19.10.2020).

DOI https://doi.org/10.30525/978-9934-588-92-1-72

\title{
ДО ПИТАННЯ РЕГУЛЮВАННЯ ТЕХНОЛОГІЇ ОТТ У СФЕРІ АУДІОВІЗУАЛЬНИХ МЕДІА ПОСЛУГ В УКРАЇНІ
}

\author{
Шрам С. О. \\ студентка магістратури другого року навчання \\ Інституту права
}

Київського національного університету імені Тараса Шевченка м. Київ, Украӥна

Технологія over-the-top (OTT) - технологія доступу до програмного продукту, що дозволяе кінцевим користувачам отримувати різноманітний вміст, зокрема аудіовізуальний, в режимі реального часу незалежно від мереж операторів та провайдерів телекомунікаційних послуг завдяки підключенню до мережі Інтернет. За визначенням 
Міжнародного союзу електрозв'язку, ОТТ - програмний продукт, доступ до якого здійснюється через загальнодоступний Інтернет, і який може бути прямим технічним / функціональним замінником

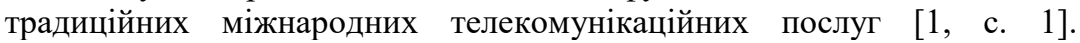
Сьогодні така технологія особливо поширена у сфері аудіовізуальних медіа послуг. Прикладами такого використання ОТТ $є$ платформи Netflix, HBO, Megogo, oll. Tv та інші. Наразі очікується, що ринок технології зросте на 17,1\% протягом до 2025 р. і досягне приблизно 3,49 млрд. доларів [2, с. 101].

Відповідно, активно обговорюється та актуально питання регулювання надання послуг з використанням технології ОТТ, зокрема у сфері аудіовізуальних медіа послуг. Оскільки платформи ОТТ створюють конкуренцію та альтернативу телебаченню, розглядається i аналогічний підхід для регулювання з боку органів публічної влади. Наразі такий сформований в Україні. Мета цієї роботи - проаналізувати поточну практика регулювання використання технології ОТТ у сфері аудіовізуальних медіа послуг в Україні, її ефективність та доцільність.

Серед дослідників, які аналізували питання регулювання технології ОТТ зокрема, Щеголь Г., Ебру Текін Білбіл, Маханагар Дорсанчар Бхаван, Джавахар Лал Неру Марг та ін.

У контексті технології ОТТ, звертаємо увагу, що відповідно до ст. 7 Закону України «Про ліцензування видів господарської діяльності», ліцензуванню підлягає діяльність в сфері телебачення і радіомовлення відповідно до Закону України «Про телебачення і радіомовлення» (Закон), тобто різні види мовлення і діяльність провайдерів програмної послуги.

Згідно ст. 1 Закону, мовлення - створення (комплектування та/або пакетування) і розповсюдження програм, пакетів програм, передач 3 використанням технічних засобів телекомунікацій для публічного приймання за допомогою побутових теле- та радіоприймачів $\mathrm{y}$ відкритий спосіб чи за абонентну плату на договірних засадах.

Більше нас цікавить діяльність провайдерів програмної послуги. Згідно ст. 1 Закону, провайдер програмної послуги - суб'єкт господарювання, який на підставі ліцензії, виданої Національною радою України з питань телебачення та радіомовлення, на договірних засадах надає абонентам можливість перегляду пакетів програм, використовуючи для передавання цих програм ресурси багатоканальних телемереж.

Відповідно, ключовими критеріями для визначення провайдера програмної послуги є (1) пакет програм (сукупність передач) як об'єкт послуги, і (2) використання ресурсів багатоканальних телемереж для надання послуги. 
Передача - змістовно завершена частина програми, яка має відповідну назву, обсяг трансляції, авторський знак, може бути використана незалежно від інших частин програми і розглядається як цілісний інформаційний продукт (ст. 1 Закону). Важливо вказати, що передачі - особливий продукт і за логікою законодавства створюються телерадіоорганізаціями. Відповідно, одним із критеріїв передачі як об'єкта послуги є співпраця провайдера зі спеціальним суб'єктом телерадіоорганізаціями.

Багатоканальна телемережа - телекомунікаційна мережа загального користування, призначена для передавання телерадіопрограм, а також надання інших телекомунікаційних і мультимедійних послуг, здатна забезпечити одночасну трансляцію більше ніж однієї телерадіопрограми i може інтегруватися 3 іншими телекомунікаційними мережами загального користування (ст. 1 Закону). Згідно ч. 5 та ч. 6 ст. 39 Закону, провайдер програмної послуги може володіти власними ресурсами багатоканальної телемережі або використовувати ресурси третіх осіб - операторів багатоканальних мереж - на підставі договору. Таким чином, для кваліфікації в якості провайдера програмної послуги необхідна наявність в користуванні ресурсів телекомунікаційних мереж. Істотно, що такою багатоканальною телемережею може вважатися і Інтернет.

Відповідно, за умови, що за допомогою технології ОТТ розповсюджуються телерадіопередачі, результат діяльності телерадіоорганізацій, така діяльність суб’єктів господарювання може формально вимагати окремої ліцензії.

Методика розрахунків розмірів ліцензійного збору за видачу або продовження строку дії ліцензії на мовлення, ліцензії провайдера програмної послуги, визначення розміру плати за переоформлення ліцензії та видачу дубліката ліцензії на мовлення, ліцензії провайдера програмної послуги, затверджена постановою Кабінету Міністрів України від 13 квітня 2011 p. № 412, передбачає можливість ліцензування діяльності провайдерів програмних послуг за допомогою технології ОТТ шляхом встановлення коефіцієнта для розрахунку відповідного збору. При цьому ліцензування можливе тільки для населення в межах усієї території України, що означає досить великий ліцензійний збір - 1000 розмірів прожиткового мінімуму для працездатних осіб.

Також існує технічна проблема отримання ліцензії провайдера програмної послуги при використанні технології ОТТ. Згідно п. 2.4 Положення про порядок видачі ліцензії провайдера програмної послуги, затвердженого рішенням Національної ради України з питань телебачення і радіомовлення 28.12.2011 № 2979, при поданні заяви про 
видачу ліцензії подається інформація про оператора багатоканальної мережі. У той же час, використання технології ОТТ передбачає доставку відеосигналу на пристрій користувача мережі Інтернет переважно без участі такого оператора.

Виходячи 3 викладеного та оскільки Національна рада України 3 питань телебачення і радіомовлення є органом державної влади i уповноважений діяти тільки в рамках закону, у регулятора відсутні підстави для видачі ліцензій. Такий висновок, зокрема, було підтверджено і Київським апеляційним адміністративним судом рішенням від 24 липня 2014 у справі № 826/16381/13-а.

3 огляду на описані вище проблеми регулювання технології ОТТ, в Україні склалася неоднозначна регуляторна практика. 3 одного боку законом не вимагається обов'язкове отримання ліцензії, з іншого боку формально відповідна ліцензія передбачена. На даний момент провайдери програмної послуги 3 використанням технології ОТТ фактично отримують ліцензії за бажанням. Так, наразі нам відомо всього про 4 провайдерів програмної послуги, які отримали ліцензію на діяльність 3 використанням технології ОТТ, згідно 3 Державним реєстром суб'єктів інформаційної діяльності у сфері телебачення і радіомовлення. У 3 таких провайдерів укладені договори з операторами багатоканальної телемережі, а 1 з провайдерів володіє власними ресурсами і також уповноважений на здійснення діяльності оператора багатоканальної телемережі за окремою ліцензією [3].

Важливо наголосити, що ліцензування аудіовізуальних послуг, що надаються з використанням технології ОТТ, наразі суперечить практиці та підходу світової спільноти, зокрема досвіду Свропейського Союзу. Директива 2010/13/СС Європейського Парламенту та Ради Європи про узгодження певних положень, визначених законами, підзаконними актами та адміністративними положеннями у державах-членах стосовно надання аудіовізуальних медіа послуг від 10 березня 2010 року (Директива) встановлює низку мінімальних вимог щодо сектора аудіовізуальних медіа послуг. Серед іншого, Директива звертає увагу, що жодне 3 положень Директиви не повинне вимагати або заохочувати держави-члени створювати нові системи ліцензування або адміністративних дозволів на будь-який вид аудіовізуальних медіа послуг. Аудіовізуальні медіа послуги на замовлення відрізняються від телевізійного мовлення можливістю 3 боку користувача обирати i контролювати ці послуги, а також їхнім впливом на громадськість. Це виправдовує застосування послабленого режиму регулювання аудіовізуальних медіа послуг на замовлення, який передбачає дотримання лише основних правил, визначених у цій Директиві [4, с. 31]. 
Наразі в парламенті готується до повторного першого читання i активно обговорюється проект Закону України «Про медіа» № 2693, зареєстрований від 27 грудня 2019 р. Він покликаний врегулювати, в тому числі питання ліцензування сервісів відео за запитом. У поточній редакції законопроект передбачає ліцензування лише у зв'язку 3 використанням радіочастотного ресурсу для надання послуг, тобто сервіси відео за запитом, в т.ч. такі, що використовують технологію OTT, не підлягають ліцензуванню. Однак, так як законопроект ще не прийнятий в першому читанні (за основу), його положення можуть істотно змінитися, а сам законопроект може і не стати законом.

\section{Література:}

1. Recommendation of ITU D.262 (05/19): Collaborative framework for OTTs. 2019. URL: https://www.itu.int/itu-t/recommendations/rec.aspx?rec= 13595 (дата звернення 25.10.2020)

2. Ebru Tekin Bilbil «Methodology for the Regulation of Over-the-top (OTT) Services: The Need of A Multi-dimensional Perspective. International Journal of Economics and Financial Issues. 2018. № 8(1). P. 101-110. URL: https://www.econjournals.com/index.php/ijefi/article/ download/5809/pdf (дата звернення 25.10.2020)

3. Державний реєстр суб'єктів інформаційної діяльності у сфері телебачення і радіомовлення. URL: https://www.nrada.gov.ua/derzhavnyjreyestr-sub-yektiv-informatsijnoyi-diyalnosti-u-sferi-telebachennyaradiomovlennya/ (дата звернення 25.10.2020)

4. Щеголь Г. Зелена книга. Ринок ОTT-відеоконтенту. URL: https://cdn.regulation.gov.ua/d4/82/12/c2/regulation.gov.ua_Green\%20Book $\% 200 T$ T20video\%20content.pdf (дата звернення 25.10.2020) 